\title{
Evolution of cryoconite holes and their contribution to meltwater runoff from glaciers in the McMurdo Dry Valleys, Antarctica
}

\author{
Andrew G. FOUntain, ${ }^{1}$ Martyn TRAnTER, ${ }^{2}$ Thomas H. NYLEN, ${ }^{1}$ Karen J. LEWIS, ${ }^{3}$ \\ DereK R. MUELLER ${ }^{4 *}$ \\ ${ }^{1}$ Departments of Geology and Geography, Portland State University, Portland, Oregon 97207-0750, U.S.A. \\ E-mail:fountain@pdx.edu \\ ${ }^{2}$ Bristol Glaciology Centre, Bristol University, Bristol BS8 1SS, England \\ ${ }^{3}$ Institute of Arctic and Alpine Research, University of Colorado, Boulder, Colorado 80309-0450, U.S.A. \\ ${ }^{4}$ Département de Biologie and Centre d'Études Nordiques, Université Laval, Sainte-Foy,Québec G1K 7P4, Canada
}

\begin{abstract}
Cryoconite holes are water-filled holes in the surface of a glacier caused by enhanced ice melt around trapped sediment. Measurements on the ablation zones of four glaciers in Taylor Valley, Antarctica, show that cryoconite holes cover about $4-6 \%$ of the ice surface. They typically vary in diameter from 5 to $145 \mathrm{~cm}$, with depths ranging from 4 to $56 \mathrm{~cm}$. In some cases, huge holes form with $5 \mathrm{~m}$ depths and $30 \mathrm{~m}$ diameters. Unlike cryoconite holes elsewhere, these have ice lids up to $36 \mathrm{~cm}$ thick and melt from within each spring. About one-half of the holes are connected to the near-surface hydrologic system and the remainder are isolated. The duration of isolation, estimated from the chloride accumulation in hole waters, commonly shows ages of several years, with one hole of 10 years. The cryoconite holes in the McMurdo Dry Valleys create a near-surface hydrologic system tens of $\mathrm{cm}$ below the ice surface. The glacier surface itself is generally frozen and dry. Comparison of water levels between holes a few meters apart shows independent cycles of water storage and release. Most likely, local freeze-thaw effects control water passage and therefore temporary storage. Rough calculations indicate that the holes generate at least $13 \%$ of the observed runoff on the one glacier measured. This hydrologic system represents the transition between a melting ice cover with supraglacial streams and one entirely frozen and absent of water.
\end{abstract}

\section{INTRODUCTION}

Cryoconite holes are vertical cylindrical melt holes in the glacier surface, which have a thin layer of sediment at the bottom and are filled with water. The Swedish explorer A. E. Nordenskjöld first named these melt holes during his 1870 Greenland expedition: "cryo" means ice and "conite" means dust (Leslie, 1879). Cryoconite holes are common to the ablation zone of glaciers worldwide, including the Arctic (Drygalski, 1897; Säwström and others, 2002), temperate glaciers of the mid-latitudes (Wharton and Vinyard, 1983; McIntyre, 1984; Margesin and others, 2002) and the Antarctic (Wharton and others, 1985; Mueller and others, 2001). On most glaciers, particularly those in temperate zones, the holes form water-filled pools, with typical horizontal and vertical dimensions of $\sim<10 \mathrm{~cm}$, with maximum dimensions $<1 \mathrm{~m}$.

Cryoconite holes are not limited to glaciers, but also appear on sea ice and lake ice. Nansen (1906) first reported cryoconite holes on the sea ice. More recently, others have investigated the processes of formation and evolution (Paige, 1968; Ishikawa and Kobayashi, 1985; Podgorny and

* Present address: S. S. Papadopulos \& Assoc., Inc., 1877 Broadway, Suite 703, Boulder, Colorado 80302-5245, U.S.A.
Grenfell, 1996). Gryoconite holes have not been explicitly recognized as such on the permanent ice-covered lakes of the McMurdo Dry Valleys, but features with similar formation mechanisms have been studied (Fritsen and Priscu, 1998) and can be considered as cryoconite holes. The holes have been known by a variety of names, including dust wells, dust basins, subsurface melt pools and baignoires (Agassiz, 1847; Hobbs, 1911; Sharp, 1949), the latter being a name for large ( $\sim 1$ m diameter) elongated, bath-tub-shaped features.

The holes form from sediment deposits that preferentially melt into the ice due to the lower albedo (greater absorption of solar radiation) of sediment compared to the bare ice. As the holes deepen, the rate of deepening slows due to a reduction in radiation energy as the optical depth along the ray path to the sediment increases. A steady-state depth is reached when the downward melt rate equals the ablation rate of the glacier surface (Gribbon, 1979; Wharton and others, 1985). McIntyre (1984) showed that the most rapid development of the holes occurred during clear weather dominated by solar radiation, supporting Gribbon's (1979) hypothesis. In addition to the physical sources of energy for melting, biological energy may also contribute to melting. Cryoconite holes typically contain microbial organisms (Steinböck, 1936) and produce some heat for melting (Gerdel and Drouet, 1960). The organisms include tardigrades, rotifers (De Smet and Van Rompu, 1994; Gron- 


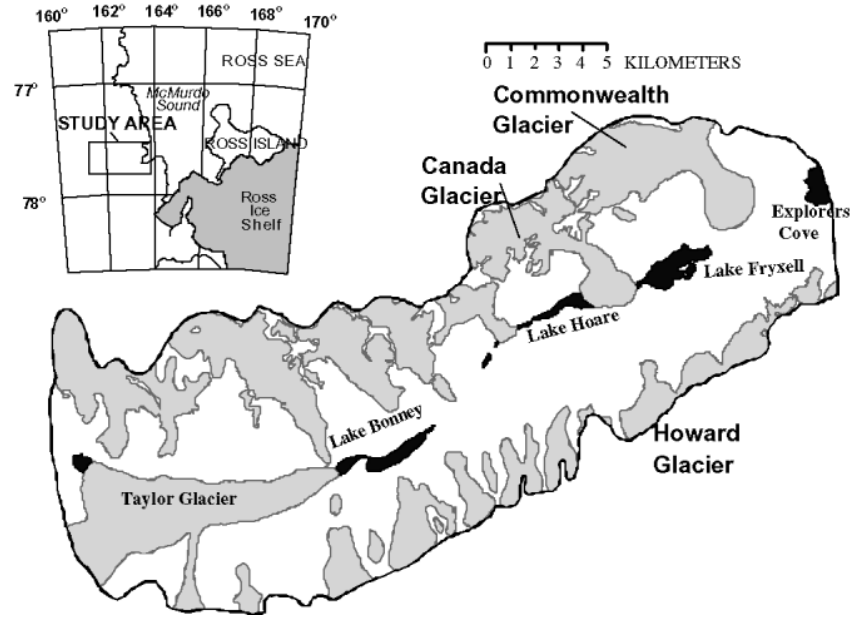

Fig. 1. Map of Taylor Valley, Antarctica. The circle on Canada Glacier indicates the location where the hydrological measurements took place (Fig. 5) and where the subsurface drainage system was mapped ( Fig. 6). The black line around the valley marks the watershed. The western boundary is somewhat arbitrary.

gaard and others, 1999; Takeuchi and others, 2000), protozoa, copepods, insect larvae (Kohshima, 1984; Kikuchi, 1994) and cyanobacteria (Gerdel and Drouet, 1960; Wharton and others, 1981). Field experiments have shown that when the micro-organisms are killed the holes are 10\% less deep than those with active organisms (McIntyre, 1984). Steinböck (1936) speculated that the importance of metabolic energy may increase with latitude as the other sources of energy decrease. The eventual decay of holes results from water freezing in the holes as winter approaches or their becoming incorporated into supraglacial streams (McIntyre, 1984).

This report describes the physical and hydrological characteristics of cryoconite holes on the glaciers of Taylor Valley, Antarctica, and tests the hypothesis that the holes are a source of meltwater runoff. Very little surface water is observed on the glaciers in this region, despite streams flowing from the glaciers. Closer observations reveal a subsurface water system, a few tens of $\mathrm{cm}$ below the surface, composed of ice-lidded cryoconite holes with interconnected passages. The motivation for this work is to support the efforts of the McMurdo DryValleys Long Term Ecological Research project, an interdisciplinary study of the physical controls on the structure and functioning of a polar desert ecosystem (Fountain and others, 1999a).

\subsection{Site description}

The McMurdo Dry Valleys, Antarctica, are located on the Ross Sea coast of southern Victoria Land, Antarctica, at $\sim 77.5^{\circ} \mathrm{S}, \sim 163^{\circ} \mathrm{W}$ (Fig. 1). The valleys are a polar desert, a barren landscape dominated by a gravelly, sandy soil with enclosed, perennially ice-covered, lakes. Polar alpine glaciers descend from the surrounding $1000 \mathrm{~m}$ high mountains, and the larger glaciers reach the valley bottom where they abruptly terminate in cliffs about $20 \mathrm{~m}$ high (Chinn, 1985; Fountain and others, 1998). A few outlet glaciers from the East Antarctic ice sheet enter the valleys. Ephemeral streams flow from the glaciers to the lakes for no more than
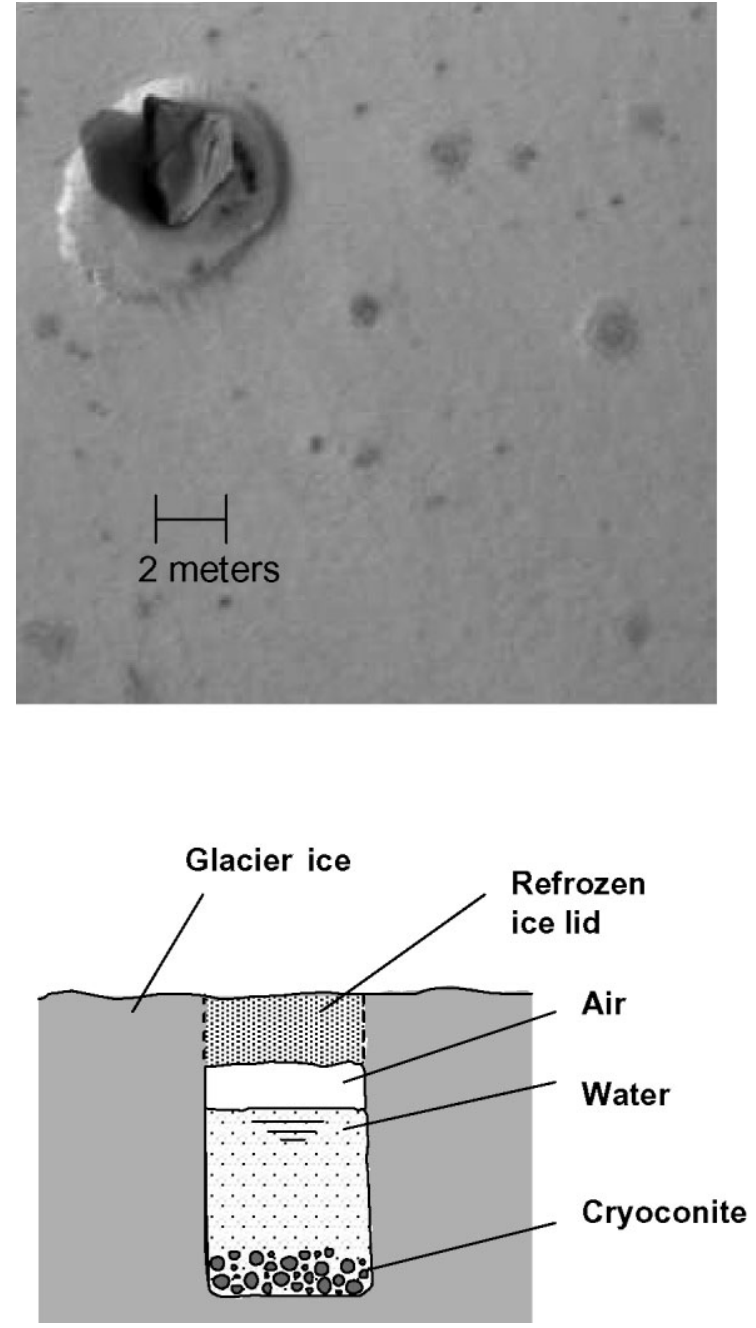

Fig. 2. On top is an aerial view of cryoconite holes on Taylor Glacier. Ice flow is to the right and north is up. Below is a schematic of a vertical cross-section of a cryoconite hole with sediment (cryoconite) at the bottom.

10 weeks during the austral summer (McKnight and others, 1999). Average annual air temperature on the valley floors varies from $-15^{\circ}$ to $-30^{\circ} \mathrm{C}$ with summer temperatures close to freezing (Doran and others, 2002). Annual precipitation (snow) in the valley bottom averages about $6 \mathrm{~cm}$ w.e. (Bromley, 1985). However, much of the snow sublimates before making a hydrologic contribution to the streams or lakes (Chinn, 1981) and glacier meltwater as the primary source to the streams and lakes.

Our study is focused on the glaciers in Taylor Valley. The western end of the valley is blocked by Taylor Glacier, an outlet glacier of the East Antarctic ice sheet, whereas the eastern end, $36 \mathrm{~km}$ away, is open to McMurdo Sound. The average annual air temperature is about $17^{\circ} \mathrm{C}$ in the valley bottom (Doran and others, 2002), and about one-third of the valley watershed, defined by the mountain peaks, is glaciercovered (Fountain and others, 1998). The glacier equilibrium-line altitude rises rapidly away from the ocean as a consequence of the decrease in precipitation and increase in sublimation due to an increase in wind speed (Fountain and others, 1999b). Mass balances of the valley glaciers reflect the desert conditions, with annual averages of no more than $\pm 5 \mathrm{~cm}$ w.e. (Fountain, unpublished data). The surface of the glacier ablation zone is generally snow-free and always exhibits a net mass loss in both summer and winter. Average ablation rates in the ablation zone are about 
$-10 \mathrm{~cm} \mathrm{a}^{-1}$ (Fountain, unpublished data). Winter (February-October) ablation is entirely by sublimation and is roughly equal to summer (November-January) ablation, which is composed of sublimation $(40-80 \%)$ and melt $(60$ $20 \%$ ) (Lewis and others, 1998).

\subsection{Previous work in Taylor Valley}

Cryoconite holes in the dry valleys were first observed by Scott's expedition (Taylor, 1916; Wright and Priestly, 1922). Later Wharton and others (1981), Mueller and others (2001) and Porazinska and others (2004) examined the biodiversity within the holes in Taylor Valley. Mueller and others (2001) also studied the physical characteristics and found that from five circular plots, each $5 \mathrm{~m}$ in radius, the surface area covered by the holes ranged from $0 \%$ near the snowline to $8.6 \%$ near the glacier terminus and averaged about $3.5 \%$. The average diameter of all the holes was $27.1 \mathrm{~cm}$. Internal dimensions for a subset of holes $>10 \mathrm{~cm}$ in diameter were: depth $32.4 \mathrm{~cm}$; thickness of ice lid $14.1 \mathrm{~cm}$; air space $3.8 \mathrm{~cm}$; and water depth $14.3 \mathrm{~cm}$. A sediment layer, $<0.5 \mathrm{~cm}$ thick, covers the bottom of each hole.

Tranter and others (2004) examined the hydrochemistry of the cryoconite holes from three glaciers in Taylor Valley and found extreme values in some holes. The water could be tea-colored with $\mathrm{pH}$ values approaching $11, \mathrm{pCO}_{2}$ of about $10^{-6}$ atms, and saturation with respect to $\mathrm{CaCO}_{3}$. These high $\mathrm{pH}$ values are more typical of African soda lakes than of surface waters on glaciers. Tranter and others (2004) inferred that these extreme values must be organically controlled in a closed system, which derives its nutrients from the dissolution of the sediments and gases trapped in the ice.

\section{GRYOCONITE HOLE DISTRIBUTION AND GEOMETRY}

\subsection{Methods and results}

In the austral summer of 1998/99, we used several poles in the ablation zone of Commonwealth, Canada, Howard and Taylor Glaciers (Fig. 1), installed for mass-balance measurements, as sites to measure the cryoconite diameter and population. A $5 \mathrm{~m}$ long rope was looped over the pole, and all the cryoconite holes were measured within the $5 \mathrm{~m}$ radius circle inscribed by the rope. Only the diameter of each hole, two perpendicular measurements each, was measured. A hole was identified by a circular patch of darker ice (Fig. 2). Although none of these holes were drilled to verify the existence of subsurface water, based on our experience with holes $>10 \mathrm{~cm}$ in diameter, we knew they contained water. We speculate that the smaller holes $(<10 \mathrm{~cm})$ had or have water in them. All the holes encountered were close to circular in shape and were covered by an ice lid.

Hole diameters ranged from $<5 \mathrm{~cm}$ to $145 \mathrm{~cm}$ (Fig. 3). An analysis of variance showed that the populations are statistically different between glaciers $(p<0.002 ; p$ value is the probability of obtaining the test result by random chance), except for Taylor and Commonwealth Glaciers $(p=0.65)$. These two glaciers show a skewed distribution of holes towards smaller diameters. Canada and Howard Glaciers show a fairly flat distribution of diameters. The average diameters differ among glaciers, with the largest mean diameters found on Howard Glacier, then Canada Glacier,
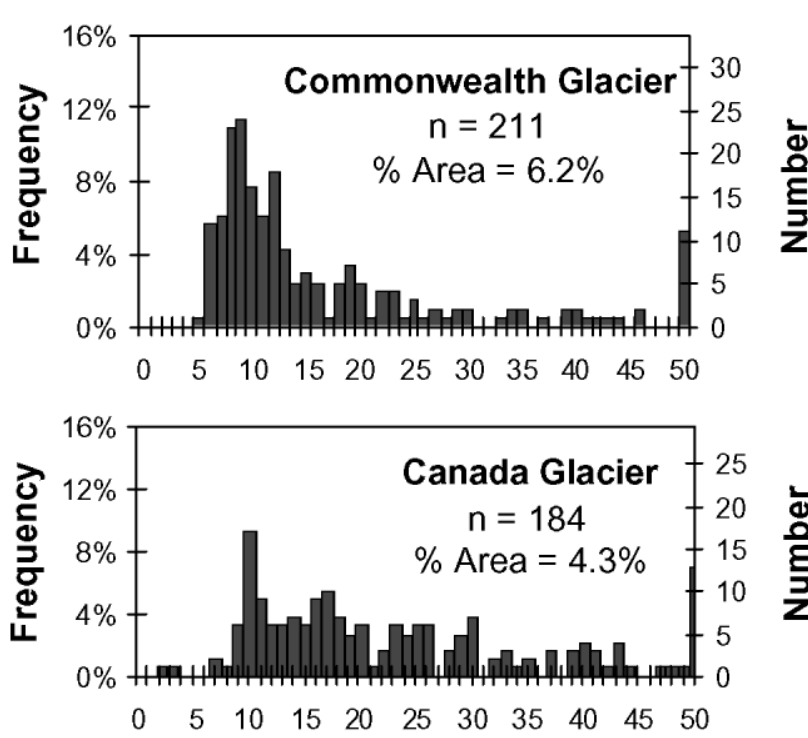

ํํํ
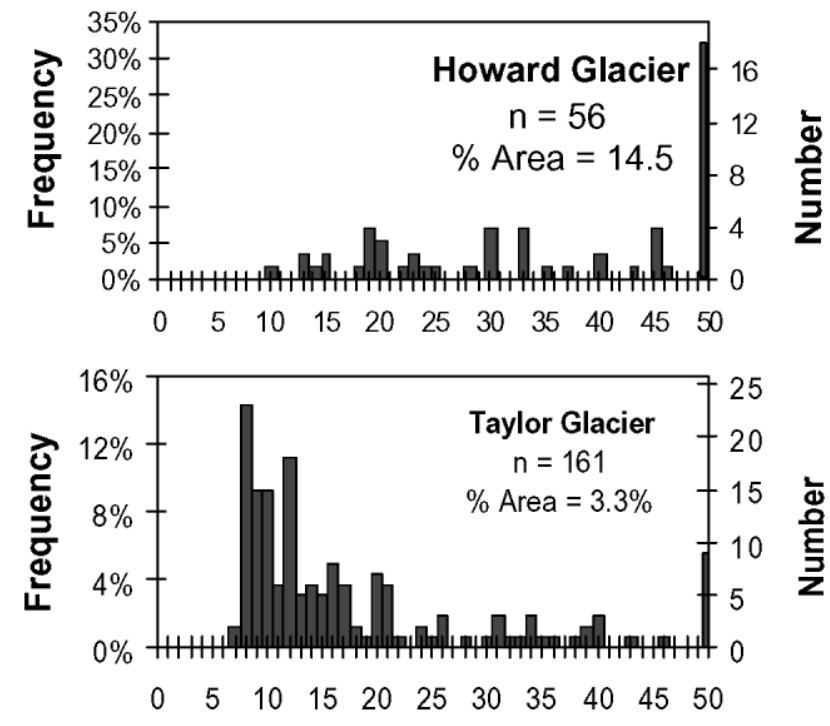

Size interval

Fig. 3. Frequency distribution of the cryoconite hole diameter. The size interval of $50 \mathrm{~cm}$ includes all the measured holes greater than $50 \mathrm{~cm}$. Note the difference in frequency scale for Howard Glacier.

with Commonwealth and Taylor Glaciers showing smaller and similar diameters (Table 1). The number of holes per unit area is nearly the inverse, with the fewest holes on Howard Glacier and the greatest number on Commonwealth and Taylor Glaciers. The fractional area covered by cryoconite holes is greatest on Howard Glacier $(6.4 \%$ of the surface area), exceeding all other glaciers and almost twice the coverage on Taylor Glacier $(3.4 \%)$. These statistics must be used with some caution, as the number of holes per unit area can change across the ablation zone of a glacier (Takeuchi and others, 2000; Johnston, 2003).

We collected data on the depth and diameter of cryoconite holes in field seasons 1998/99, 1999/2000 and 2000/01 (Fig. 4). The depth of the cryoconite holes varies from 4 to $56 \mathrm{~cm}$. We believe this range to be somewhat limited by our sample size, particularly for the large diameters, as will be discussed later. Contrary to studies in other regions (Gribbon, 1979), we found no relation between hole depth and altitude over the $500 \mathrm{~m}$ range measured. There seems to be a general relation of increasing depth with increasing hole 
Table 1. Surfacial characteristics of the cryoconite holes

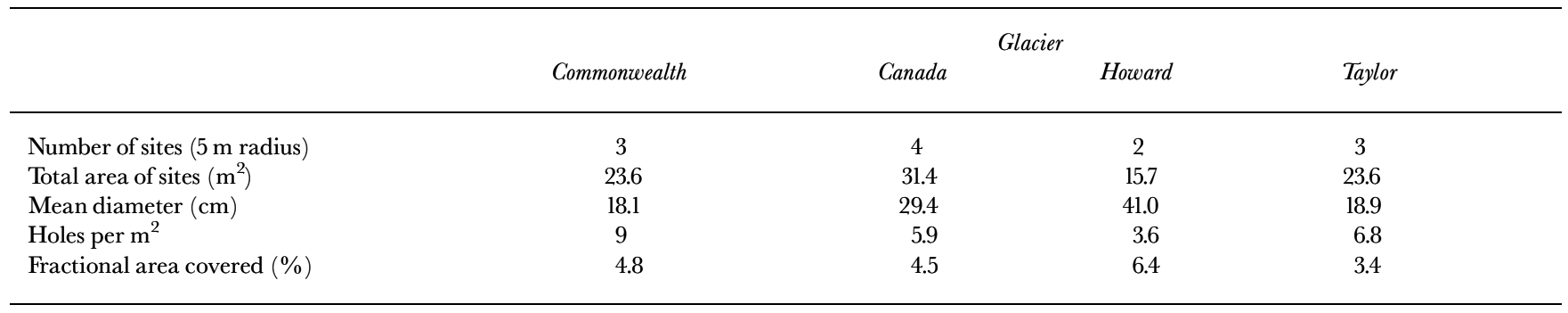

size up to about $20-30 \mathrm{~cm}$ deep, after which the visual correlation breaks down. No overall significant statistical correlation exists. On a subset of holes, the thickness of the ice lid varied between 9 and $36 \mathrm{~cm}$.

\subsection{Analysis and interpretation}

The distributions of hole diameters between glaciers may suggest different sediment fluxes and perhaps sources. The skewed distribution found on Taylor and Commonwealth Glaciers may imply an aeolian sediment source, as the many small holes indicate sediment dispersal into small patches. If more sediment were available and less dispersed, presumably larger holes would develop, like the flat distribution of Canada and Howard Glaciers. On these two gla-
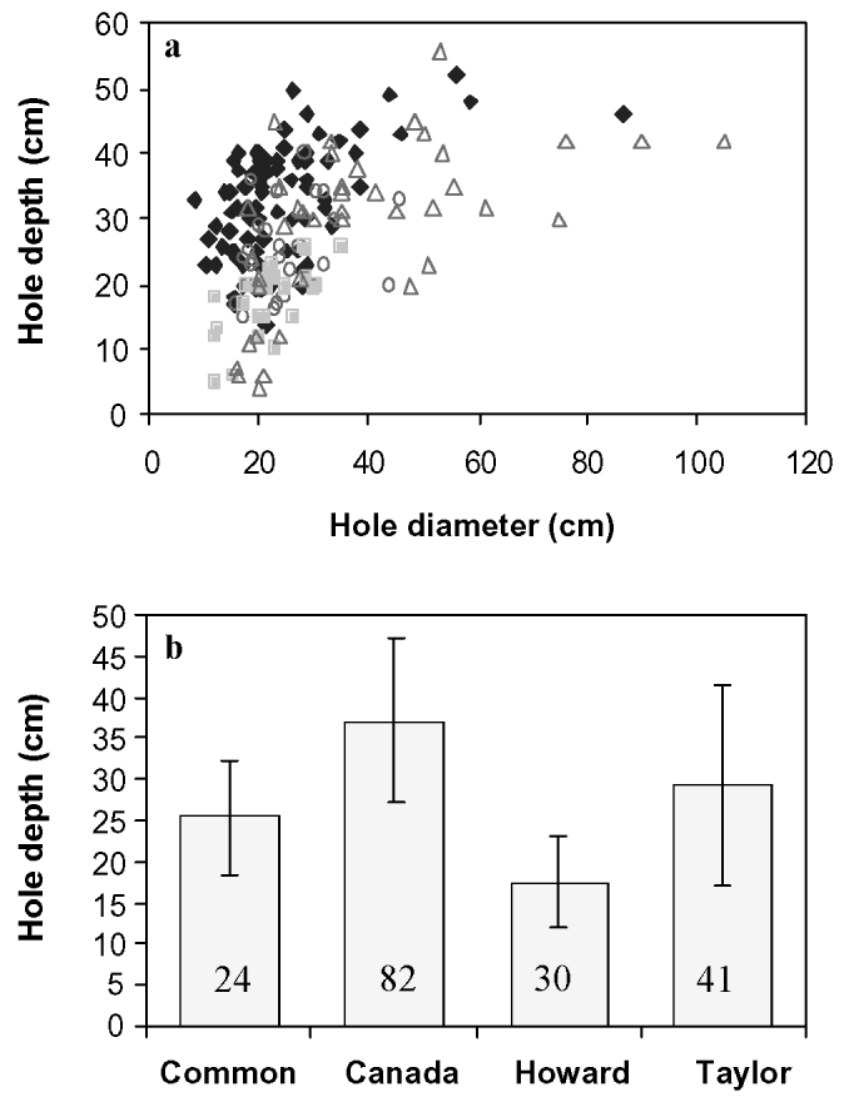

Fig. 4. Cryoconite hole diameters and depths for each glacier. (a) The relation between cryoconite diameter and depth for all glaciers. The open circles represent Commonwealth Glacier; the solid diamonds Canada Glacier; the solid squares Howard Glacier; and the open triangles Taylor Glacier. (b) The mean depth of the cryoconite holes, with the standard deviation plotted as an error bar. The numbers represent the sample size for each glacier. ciers, sediment sources may also include avalanching from the adjacent steep valley walls, which directly contact the glacier in the upper ablation zone or lower accumulation zone. Some of this sediment may be advected through the ice to the surface of the ablation zone. Support for an avalanche source is provided by grain-sizes of sediment found in cryoconite holes on Canada Glacier. About $60 \%$ of the sediment mass is from grains $>1 \mathrm{~mm}$ in diameter. In local aeolian-deposited sand dunes on the valley floor, about $75 \%$ of the mass is composed of grain-sizes $<0.25 \mathrm{~mm}$ in diameter. Our findings support those of Sharp (1949) who identified aeolian and avalanche sediment sources for cryoconite development.

The scatter of hole-depth/-diameter data (Fig. 4) may reflect both developing and mature cryoconite holes. The developing holes are melting down into the ice and have not reached their equilibrium depth, whereas the mature holes have reached their equilibrium depth. Intuitively, one expects a relation between diameter and depth, but numerous factors interact to confuse this simple relation. The initial size of the sediment patch probably determines diameter, as we see no evidence to suggest small holes merge. This notion differs from cryoconite holes without ice lids in more temperate climates where merging cryoconite holes are often observed (Gaijda, 1958; McIntyre, 1984). The depth of the hole may be affected by sediment thickness. For subaerial conditions, sediment thicknesses greater than some critical value (few tens of $\mathrm{mm}$ ) insulate the ice and retard ablation compared to clean ice, whereas sediment accumulations less than the critical value increase ablation (Driedger, 1981; Adhikary and others, 2000). We presume a similar process occurs in the water-filled cryoconite holes. If thick sediments cover the hole bottom, the solar energy absorbed by the sediment heats the water and may enlarge the hole diameter. Spatial variations in ice transmissivity may also be a factor. In clear ice, cryoconite holes should be deeper than in bubbly ice, which scatters the incoming solar radiation.

The depth/diameter data tend to cluster for each of the glaciers (Fig. 4a), except for Taylor Glacier, which nearly spans the data range of all the other glaciers together. The diameters differ from Table 1 and Figure 3 because the sample size is different and we tended to drill into larger holes. The average hole depth (Fig. 4b) is greatest for Canada Glacier and least for Howard Glacier. The reason for these variations is unclear, although it might be related, as previously described, to sediment flux, slope and aspect, albedo characteristics of the glacier surface and transmissivity of the ice. Another possibility is spatial differences in ice temperature, which is strongly influenced by local air temperature and can vary in the valley by several ${ }^{\circ} \mathrm{C}$ (Doran and others, 2002).

In agreement with Takeuchi and others (2000), and dif- 
Downslope

Glacier Direction

b
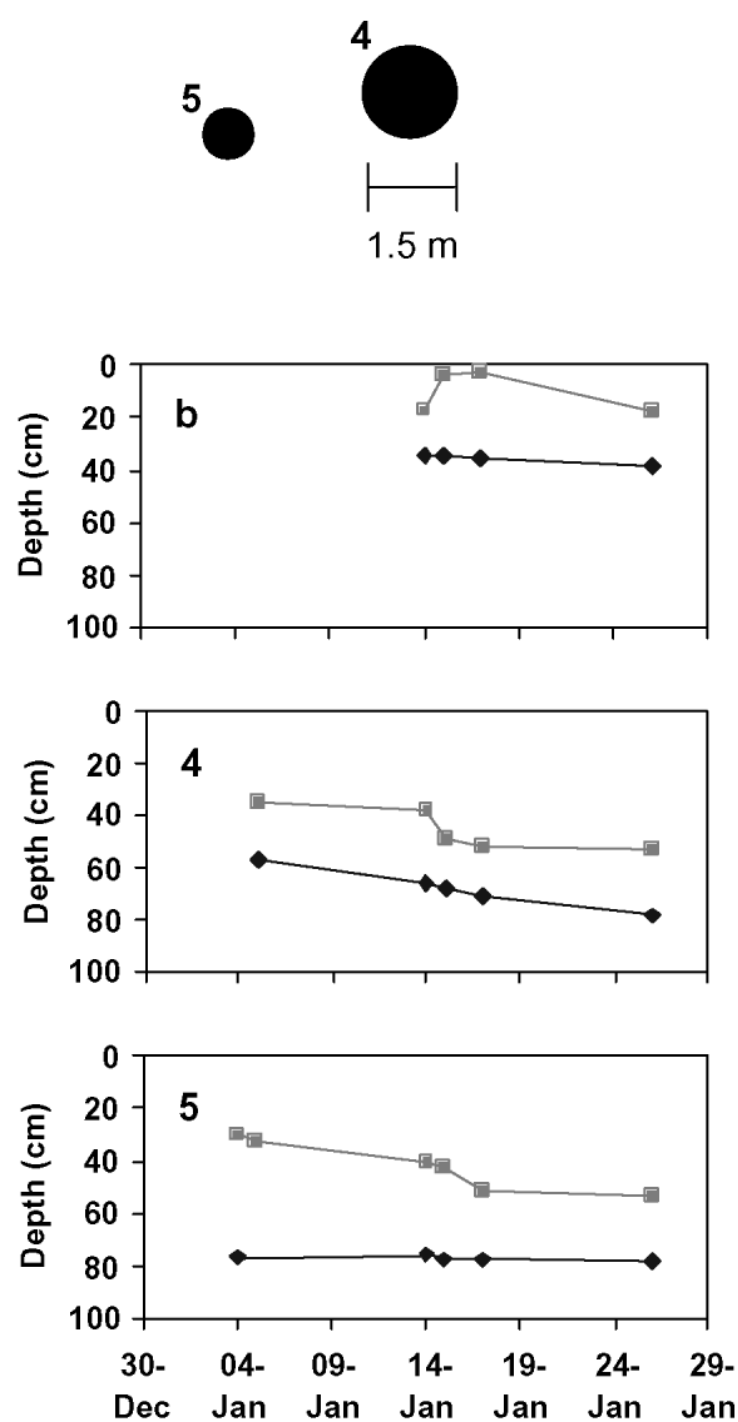

Fig. 5. Top panel is the approximate arrangement of the monitored cryoconite holes. The three graphs below measure the depth to the ice surface of the cryoconite hole, a proxy for the water surface (squares), and to the sediment layer at the bottom of the hole (diamonds), for holes $b, 4$ and 5 , respectively. The datum is arbitrary.

fering with Gribbon (1979), we did not observe any relation between elevation and hole depth. Perhaps this is because of differences in the time the ice is exposed to sunlight in temperate conditions and polar conditions. In temperate conditions, the ice is exposed only after the snow melts away and the snowline recedes to higher elevations. So cryoconite holes near the terminus can be sun-exposed for several months whereas those near the equilibrium line may be exposed for only a couple of weeks. In the dry valleys, the ablation zone is generally snow-free all year long. Even in winter the ablation zone experiences a negative mass balance (Fountain and others, 1998). When snow temporarily accumulates on the ablation zone, it usually covers the entire ablation zone. Therefore, the holes across the ablation zone have nearly equal exposure time to the sun.

\section{HYDROLOGY OF GRYOCONITE HOLES}

\subsection{Methods and results}

During the summer of 2001/02, three relatively large cryoconite holes on Canada Glacier, b, 4 and 5, were repeatedly measured by hand for nearly a month. The site was located near the center of the ablation zone (Fig. 1) at an altitude of $230 \mathrm{~m}$ and on a slope of about $4^{\circ}$. This region is generally representative of the glacier surface. Hole b was $25 \mathrm{~cm}$ in diameter and initially $35 \mathrm{~cm}$ deep. Hole 4 was about $150 \mathrm{~cm}$ in diameter and initially $76 \mathrm{~cm}$ deep, and hole 5 was about $60 \mathrm{~cm}$ in diameter and $57 \mathrm{~cm}$ deep. Measurements of distance to the ice lid and to the sediment in the bottom of the hole were made from a fixed reference, a horizontal bamboo pole suspended between two vertical poles drilled into the ice. An extreme melting event occurred in mid-December that melted away the lids of most cryoconite holes. We observed subsurface channels connecting to holes 4 and 5 . Hole b appeared to be isolated. Thin ice covers developed on the hole water and reformed when the water changed level substantially. So for our purposes, a measure to the ice cover provided a proxy measure to the water surface. Results showed substantial changes in water levels (Fig. 5). The two larger holes (4 and 5) generally drained over the measurement period, and the smallest hole (b) gained some water before draining. The change in hole $b$ was surprising because no channels were obvious and we thought it hydrologically isolated. The water-level changes are not synchronous between the holes.

To depict the configuration of the drainage system, we mapped drainage features over a $10 \mathrm{~m}$ by $10 \mathrm{~m}$ area on Canada Glacier about $20 \mathrm{~m}$ away from the holes in which we measured the water levels (Fig. 6). We sketched the location of each feature, measured at $0.5 \mathrm{~m}$ intervals, on scaled graph paper. Features smaller than $0.5 \mathrm{~m}$ were located within each $0.5 \mathrm{~m}$ square by eye. Clearly, the glacier is covered with a system of pools (cryoconite holes) and streams (connecting passages). Additionally, cracks in the ice may also transmit water. This system appears broadly similar to that found on the surface of temperate and polythermal glaciers (Gribbon, 1979; McIntyre, 1984).

\subsection{Analysis and interpretation}

Changes in the hole water levels reflect the lateral flux of water through the holes and, to a lesser degree, melt within the holes. Water flux is controlled by melt production in the hydraulic system and by the hydraulic resistance posed by the connecting passageways. We conjecture that the passageways enlarge by solar-radiation-induced melt and shrink by local variations in freezing. Frictional heating of flowing water (Röthlisberger, 1972) probably contributes very little to the melt enlargement in these conditions.

Changes in water level for holes 4 and 5 are broadly similar although the timing and magnitude are different, and hole $b$ is quite different altogether. The variation in timing of peak levels between holes suggests that the hydraulics are spatially variable. Local controls on the water flux must 

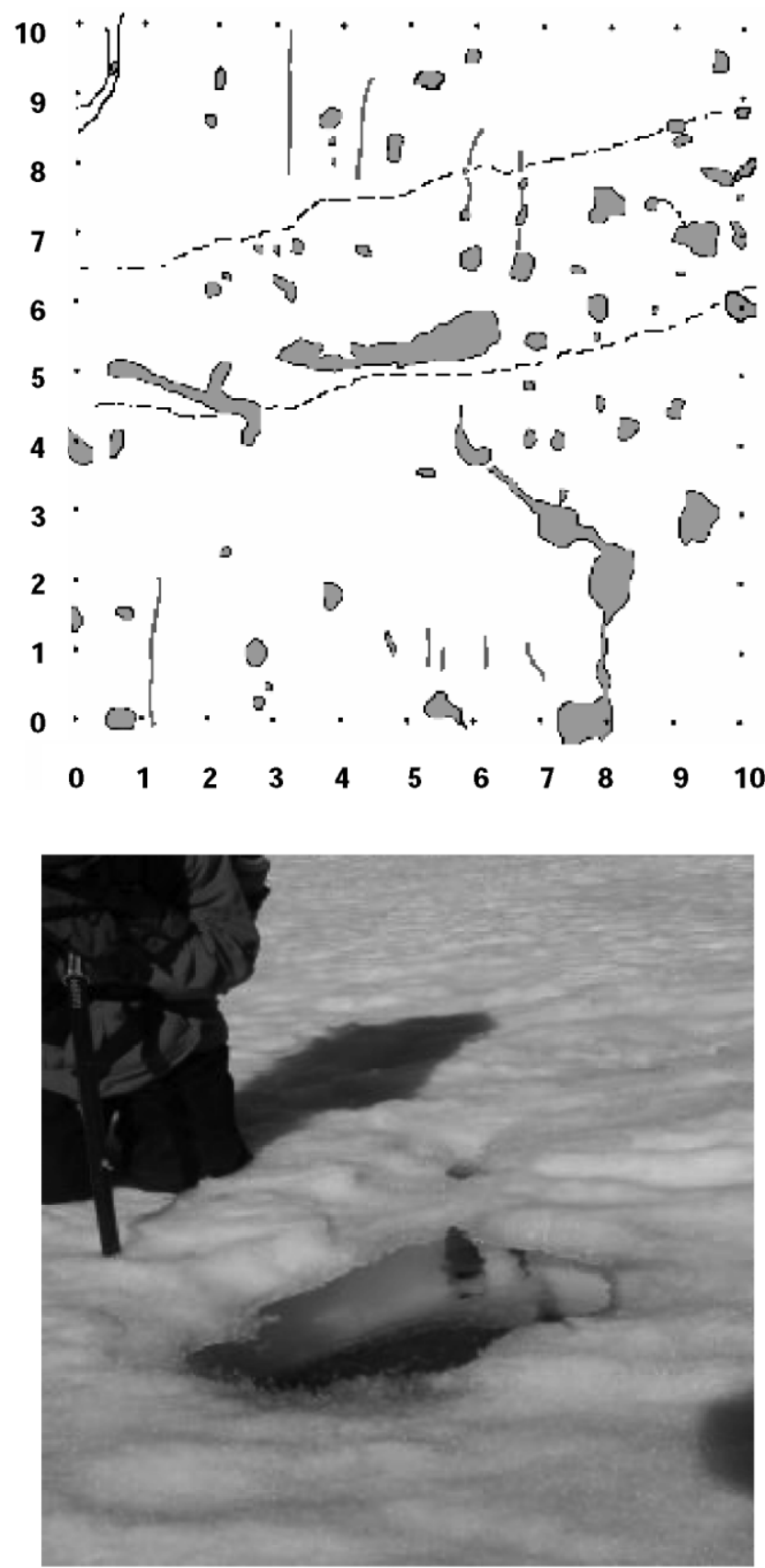

Fig. 6. Map of the subsurface hydrologic features on Canada Glacier. The scale around the perimeter is in meter intervals. The grey circular features are the cryoconite holes, the grey linear features are channels, the thin black lines are cracks, and the two dashed lines mark the perimeter of a shallow $(\sim 20 \mathrm{~cm})$ surface depression. The surface slopes downward parallel to the vertical axis which is the major flow direction of the ice. The photograph below is of an open cryoconite hole with a connecting channel. Note the person in the upper left for scale.

dominate because the climatic environment is uniform over the scale of tens of meters. Such controls might include local freezing and thawing resulting from small-scale topographic variations that cause differential solar illumination and shading. Other possible controls, such as sediment thickness and transmissivity of the ice, are relatively constant in time and should only affect flux magnitude, not peak timing. Over large areas $(>100 \mathrm{~m})$, these small-scale effects probably cancel, resulting in the diel flux of water observed in the stream-flow.
During the observation period the bottom of each hole deepened. Hole b deepened by $3.5 \mathrm{~cm}$, hole 4 by $21 \mathrm{~cm}$, and hole 5 by $2 \mathrm{~cm}$. Why differences exist in the melt rates is unknown. Hole 4, has the greatest melt rate, the largest diameter and the smallest depth-to-width ratio of 0.5 . This comparatively wide, shallow hole allows solar radiation to directly reach the water, rather than be transmitted through the ice with scattering losses. Therefore its waters warm faster and the hole melts faster. Sediment thickness on the hole bottom may also be a factor, but we have no measurements.

\subsection{Duration of hydrologic isolation for cryoconite holes}

During the normally cool summer seasons, the cryoconite holes, connecting passageways and streams are all hidden beneath the glacier surface. Under these conditions it is unclear what fraction of the cryoconite holes is hydraulically connected. During the summer of 1999/2000, we attempted to estimate the frequency of hydraulic connectivity using the chloride $\left(\mathrm{Cl}^{-}\right)$content of the hole waters. Chloride is a relatively conservative natural tracer and is often used in tracer studies in otherwise reactive environments (Zellweger, 1994).

The primary source of $\mathrm{Cl}^{-}$in the meltwater in the dry valleys is from marine aerosols (Lyons and others, in press). Chloride is a conservative ion that will accumulate in the holes as the holes melt into the glacier. Seasonal cycles of hole-water refreezing and subsequent summer melting do not affect the summer $\mathrm{Cl}^{-}$concentration as long as the hole is hydraulically isolated. The initial quantity of $\mathrm{Cl}^{-}(\mu \mathrm{mol})$, $M_{0}$, is equal to

$$
M_{0}=h a i,
$$

where $h$ is depth of hole (cm), $a$ is cross-sectional area of the hole $\left(\mathrm{cm}^{2}\right)$ and $i$ is the average concentration of $\mathrm{Cl}^{-}$ $\left.(\mu \mathrm{mol} \mathrm{L})^{-1}\right)$ in the surrounding ice. When the hole is refrozen, we assume that all the $\mathrm{Cl}^{-}$from the lid was rejected from the ice into the waters below. As the holes melt-deepen and the ice is refrozen at the ice lid, the $\mathrm{Cl}^{-}$concentration increases with time. The mass of $\mathrm{Cl}^{-}$in the hole for any time is

$$
M_{\mathrm{t}}=M_{0}+a i \frac{\mathrm{d} z}{\mathrm{~d} t}+\Delta t,
$$

where $\mathrm{d} z / \mathrm{d} t$ is the melt rate at the bottom of the cryoconite hole and $\Delta t$ is the elapsed time. Substituting Equation (1) into Equation (2) and solving for $\Delta t$ yields

$$
\Delta t=\left(\frac{M_{\mathrm{i}}}{a i}-h\right)\left(\frac{\mathrm{d} z}{\mathrm{~d} t}\right)^{-1} .
$$

The elapsed time is the age of isolation of the hole from the surrounding hydraulic system. If we assume the hole deepening is equal to the ablation (sublimation) of the ice surface (Gribbon, 1979), then the melt rate is the ablation rate for the glacier. A value of $\Delta t>0$ indicates the age in years of isolation, and a value of $\Delta t<0$ indicates water exchange with other meltwater.

On Canada Glacier, the average ablation rate in the ablation zone is about $8 \mathrm{~cm} \mathrm{a}$ w.e. The average $\mathrm{Cl}^{-}$concentration in the ice surrounding the holes was $32 \mu \mathrm{eq} \mathrm{L} \mathrm{L}^{-1}$. A depth-averaged water sample was taken from 16 holes and analyzed for $\mathrm{Cl}^{-}$. Results showed that seven holes had $t>0$ (Table 2), indicating that $44 \%$ were hydraulically isolated and $56 \%$ were connected to the water-flow system. If 
Table 2. $\mathrm{Cl}^{-}$concentrations, hole depth, and age of hydraulic isolation for cryoconite holes on Canada Glacier

\begin{tabular}{|c|c|c|}
\hline Hole depth & $\mathrm{Cl}^{-}$ & Age \\
\hline $\mathrm{cm}$ & $\mu \mathrm{mol} \mathrm{L}^{-1}$ & years \\
\hline 55 & 45 & 0 \\
\hline 60 & 46 & -2 \\
\hline 65 & 49 & 0 \\
\hline 65 & 44 & 0 \\
\hline 50 & 123 & 1 \\
\hline 56 & 55 & -1 \\
\hline 56 & 86 & 5 \\
\hline 56 & 58 & -1 \\
\hline 53 & 107 & 1 \\
\hline 45 & 826 & 11 \\
\hline 58 & 82 & 2 \\
\hline 60 & 71 & 1 \\
\hline 60 & 64 & 0 \\
\hline 51 & 101 & 0 \\
\hline 56 & 111 & 1 \\
\hline 48 & 18 & -4 \\
\hline
\end{tabular}

this sample is representative, then roughly half of the cryoconite holes produce runoff. It is interesting to note that although the majority of the holes were isolated for a year, three holes were isolated for multiple years and one for over a decade! These values support previous suggestions (Von Drygalski, 1897) as quoted by Gaijda (1958), and our notion that cryoconite holes are relatively stable features and persist from year to year.

\section{WORKING HYPOTHESES}

\subsection{Annual cycle}

Once a cryoconite hole is established, it undergoes an annual cycle. Holes reach their maximum depth in late summer under conditions of relatively warm air temperatures and intense sunshine (McIntyre, 1984). In early autumn, starting in late January, conditions cool in response to decreased solar radiation, ice forms on the open-water holes and the water within the ice-lidded holes begins to refreeze. For isolated holes, large pressures can accumulate. We have pierced new ice covers, several $\mathrm{cm}$ thick, on previously open holes and observed a jet of water 1-2 $\mathrm{m}$ high. Under great pressure, the surrounding ice may fracture, creating incipient channels. Such fracturing is observed around bubbles formed in refrozen water trapped within the lake-ice covers (Adams and others, 1998). Wright and Priestly (1922) observed the last stages of hole freeze-up during their expedition in late February and early March. They suggested that cracking around the holes drains some of the water from the holes. Eventually, all the water in the system freezes. Winter (February-October) sublimation ablates the glacier surface and decreases the depth to the sediment layer in the frozen holes. By late spring, the sediment is at its shallowest depth.

Air temperatures warm in spring, and solar radiation heats the ice and sediment; ice temperatures around the sediment warm to the melting point. The sediment begins to melt into the ice more rapidly than the ice surface ablates and the holes deepen. The onset of cryoconite melt occurs no

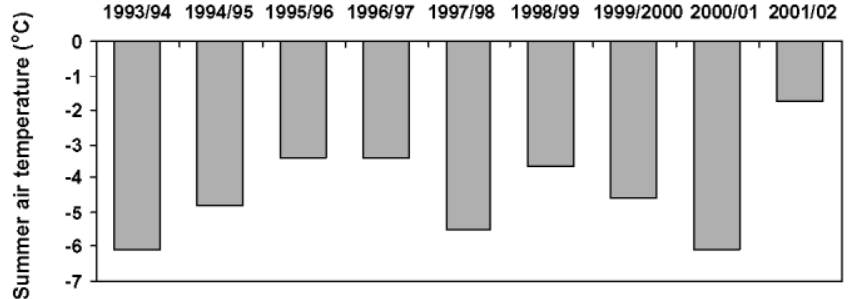

Fig. 7. The mean summer (December and January) air temperature for all four glacier meteorological stations in Taylor Valley.

earlier than mid-November since we have never encountered water in any holes by that time. The downward melting of the sediment continues until a balance is achieved between the downward melting of the hole and the ablation rate of the ice surface (Gribbon, 1979). In addition to less solar radiation at deeper depths, heat is also conducted at a faster rate away from the hole bottom as it reaches deeper depths into colder ice. The entire melt deepening of the hole occurs during summer and compensates for the winter and summer ablation. The surface remains frozen due to belowfreezing air temperatures, and high winds that keep sublimation high (Lewis and others, 1998).

\subsection{Cold and warm years}

Our meteorological measurements began in 1993, and summer (December and January) air temperatures in Taylor Valley have averaged a few ${ }^{\circ} \mathrm{C}$ below freezing (Fig. 7). During the summer of 2000/01, air temperatures averaged $-6.1^{\circ} \mathrm{C}$. Most of the cryoconite holes drilled in January 2001 were frozen to the bottom and we presume they were frozen for the entire summer. Therefore, during cold years some or most of the cryoconite holes do not melt and much of the ablation zone does not make a hydrological contribution to the stream-flow. The only contributing areas would be the cliffs along the glacier terminus and perhaps the glacier surface near the margin (Fountain and others, 1998).

Snowfall also has a great effect on cryoconite holes. Summer snow typically causes stream-flow to drop dramatically due to the increase in surface albedo of the glaciers. Little snowmelt occurs since summer air temperatures are below freezing and most of the solar radiation is reflected. Consequently, a thin snow cover can persist for weeks and prevent most shortwave radiation from penetrating into the ice. Under these conditions, the once water-filled holes begin to freeze.

The warmest summer air temperatures since 1993 occurred in the 2001/02 season, with a mean temperature of $-1.8^{\circ} \mathrm{C}$ and several days of temperatures above $4^{\circ} \mathrm{C}$. For the first time, as previously mentioned, we observed many open cryoconite holes, streams flowing over the glacier, and the presence of extensive sediment patches. We could readily see that if these conditions persisted, the near-surface water system would evolve into a supraglacial system typical of temperate and polythermal glaciers. Towards mid-January the air temperatures cooled and the holes began to refreeze. So within the climatic variation of the McMurdo Dry Valleys, we have witnessed the range of conditions from a nearentirely frozen water system to one that is almost completely melted out. Thus the subsurface cryoconite and flow-pas- 

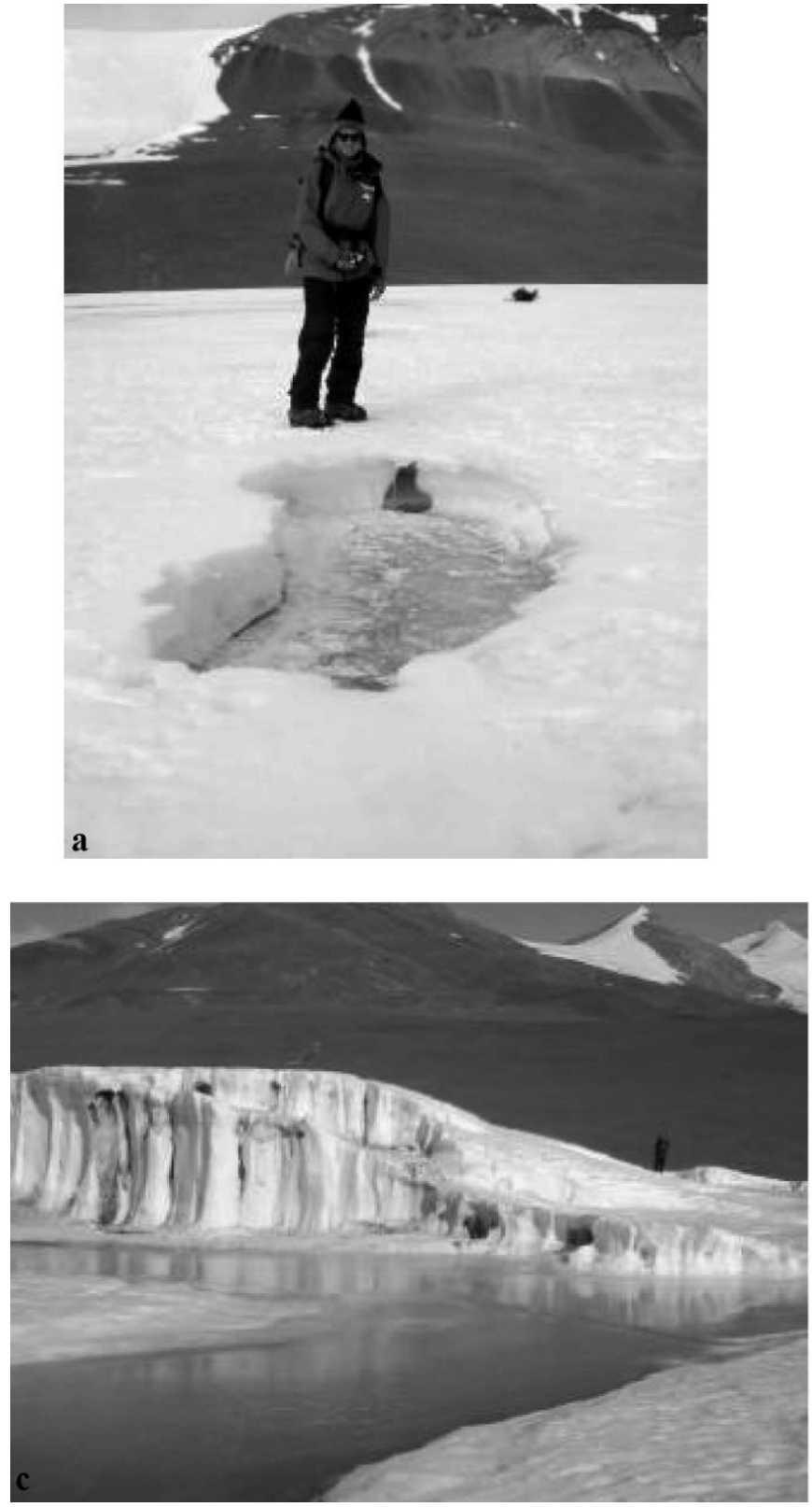
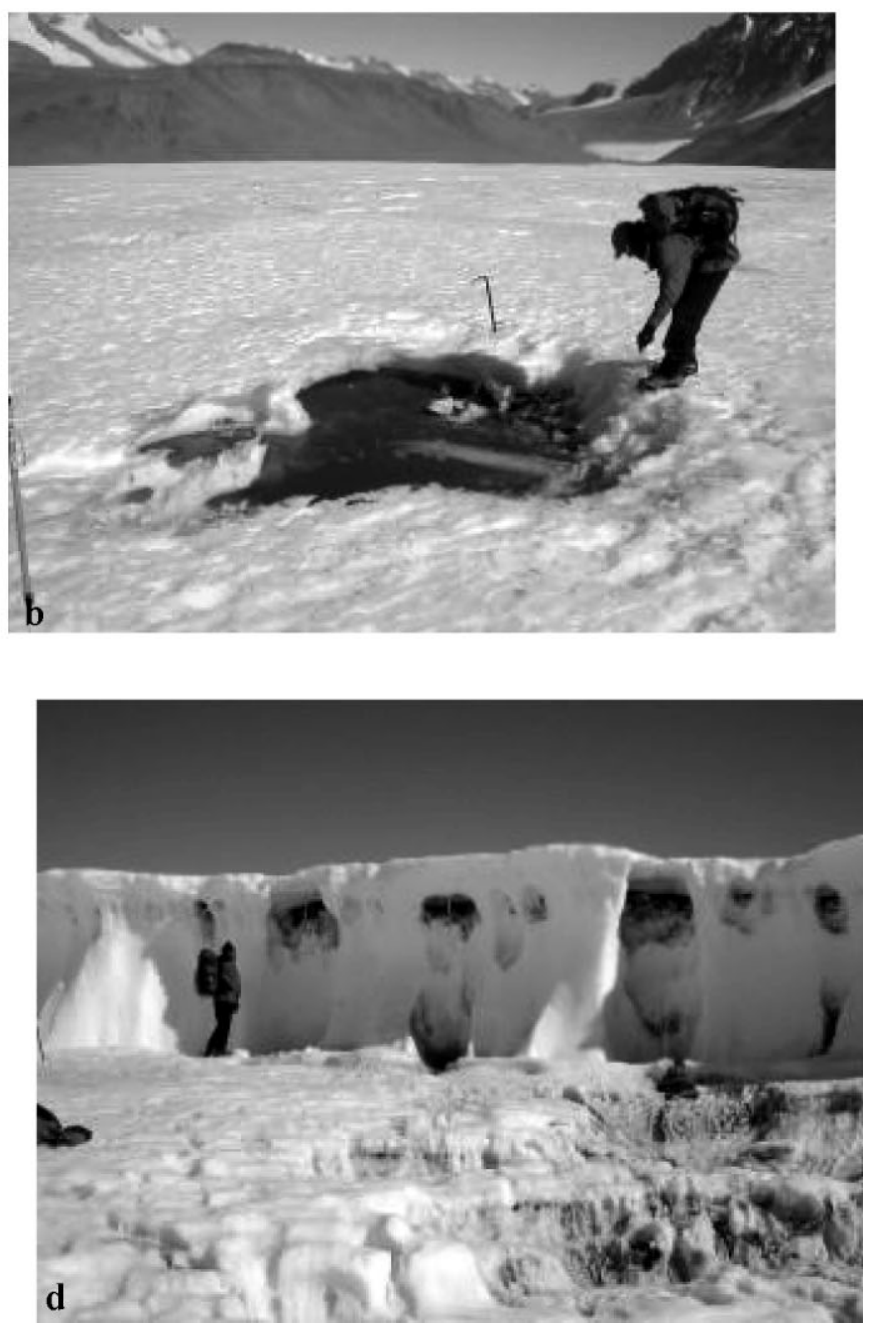

Fig. 8. Series of photographs illustrating the proposed development of a large cryoconite hole. (a) Large cryoconite hole after a drop in water level. Note the connection on the far side. (b) Enlarged hole with no ice cover, exhibiting lots of sediment. (c) Extremely large hole; note figure in background on right. Also note the scavenging of cryoconite holes in the walls. (d) Close-up of a wall. Note the intersected cryoconite holes in the wall.

sage system of "normal" years is a transitory stage between these extremes.

\subsection{Extreme cryoconite holes}

Extremely large cryoconite holes are observed on some glaciers in the dry valleys. The holes are tens of meters in diameter and $5 \mathrm{~m}$ deep, with a shallow $(\sim 0.5 \mathrm{~m})$ ice-covered slush pond at the bottom. We believe they form in the following manner. First, the hole loses its ice lid. A water-filled hole supports the ice cover, but once the hole becomes hydraulically connected, the water drains and the cover loses its support. If the hole diameter is sufficiently large, the cover fails mechanically or is weakened by solar warming and subsequently fails. The hole walls are now exposed directly to the sun and receive more intense solar radiation compared to the surrounding sub-horizontal glacier surface, due to the low solar elevation angle (maximum $36^{\circ}$ ). Additionally, multiple reflections of the solar beam within the hole enhance the incoming radiation. Although the daily total radiation is less in the holes than on the surrounding surface, because of aspect and self-shadowing, the greater intensity is important to rapidly warm the ice. Winds in the hole are much calmer than on the surrounding glacier surface, resulting in smaller turbulent heat losses (sensible and latent) and higher surface ice temperatures. These conditions favor melt, a more energy-effective ablation process, over sublimation. On sunny days, consequently, the holes deepen and widen faster than the surrounding horizontal surface ablates (Lewis, 2001). Conversely, during cloudy periods the holes trap less solar energy, ablate less than the glacier surface, and decay.

As the holes enlarge, the sediment layer at the bottom thins as it disperses across the enlarging pools of water. Sediment dispersal probably results from water passing through the hole from the near-surface hydrologic system. If thinning were to continue, the albedo of the hole bottom 
would increase, melt deepening would decrease and the hole would decay. However, sediment is resupplied to the hole as it enlarges and intersects ice-lidded cryoconite holes, the contents of which are dumped into the enlarging hole. Therefore the survival of the large holes depends, in part, on the cannibalization of other holes to maintain its sediment layer. Also, the large holes act as sediment traps for aeolian-transported sediment. The sequence of events is illustrated in Figure 8.

Large cryoconite holes do not commonly form on the glaciers. Perhaps large patches of sediment are required to initiate large holes. In addition, the sediment has to remain in place long enough to start melting-in, which in the dry valleys may take as long as months if the sediment is deposited in winter, or only a week if deposited in summer. Canada Glacier seems to be unusual in that it has a pattern of large holes aligned parallel to the primary katabatic wind direction and located on the windward side of the glacier. The large expanse of sediment on the ice of Lake Hoare, adjacent to the glacier, and the sand dunes along the lake-glacier margin certainly suggest that large fluxes of sediment are episodically blown onto the glacier.

\section{GONTRIBUTION TO RUNOFF}

Our hypothesis is that meltwater production in the cryoconite holes is a source of runoff in the McMurdo Dry Valleys. Lewis and others (1999) compared the measured stream discharge from Canada Glacier with the melt volume from the ice cliffs and found that the cliffs accounted for $18 \%$ of the runoff during two summers (1994/95 and 1995/96). The remaining $82 \%$ comes from the glacier surface. Based on runoff measurements from Andersen Creek on the west side of the glacier and Canada Stream on the east side of the glacier, the 2 year $(1994 / 95,1995 / 96)$ total runoff volume is $198 \times 10^{3} \mathrm{~m}^{3}$. From the surface topography of the glacier, these two streams drain roughly $38 \%\left(3.35 \times 10^{6} \mathrm{~m}^{2}\right)$ of the ablation zone. The remaining $62 \%$ drains directly into Lake Hoare or into unmeasured creeks. Lewis and others (1998) calculated $0.43 \mathrm{~m}$ w.e. of melt on the cliffs over the two summers. These cliffs, which define the margin of the ablation zone, are about $20 \mathrm{~m}$ high. The cliff length contributing to stream-flow is about $2.8 \mathrm{~km}$. The total volume of melt from the cliffs over the 2 years is about $24 \times 10^{3} \mathrm{~m}^{3}$. The difference between the total measured stream-flow and that derived from the cliffs is the runoff derived from the glacier surface, or $174 \times 10^{3} \mathrm{~m}^{3}$.

Cryoconite holes cover about $4.5 \%$ of the surface on Canada Glacier. For the purposes of this calculation, we assume that they are all hydrologically connected, and ignore melt contributions from the interconnecting passages. If the cryoconite hole depths keep pace with the annual ablation for the 2 years $(17.5 \mathrm{~cm}$ w.e.), then the holes produced $26 \times 10^{3} \mathrm{~m}^{3}$ of water or about $15 \%$ of the streamflow from the glacier surface or $13 \%$ of the total runoff from the glacier. For the cryoconite holes to account for the entire surface meltwater, the coverage of the holes would have to increase to $30 \%$, an unrealistically high value.

These approximate values clearly do not account for all the observed stream-flow. Our calculations ignore the large cryoconite holes that populate the lower part of the glacier. If these large holes are included in the calculation, a much greater fraction, maybe twice our estimated value, of the runoff would be explained. However, the large holes operate by different processes than the ice-lidded ones, and the two types cannot be simply grouped together. Ablation is much greater near the terminus, and consequently the rate of hole deepening (melt) is much greater. Also, there may be a greater fractional area of cryoconite holes near the margin where sediment is more frequently blown onto the glaciers. Therefore, we consider $13 \%$ of the surface runoff to be a minimum value.

\section{DISGUSSION}

Some authors suggest that cryoconite holes are important to the heat and mass balance of a glacier (Kohshima, 1984; Wharton and others, 1985; Takeuchi and others, 2000, 2001a, b). For glaciers in the dry valleys, these effects are probably small because the cryoconite hole coverage is low, $<10 \%$ of the ice surface. Of that coverage, the albedo is reduced from about 0.65 for the ice surface to about 0.5 for the cryoconite hole surface. Averaged over the glacier surface, the albedo is reduced by about $3 \%$. Other factors play a more important role in ablation, including differences in wind speed, snow cover (Fountain and others, 1999a, b) and surface orientation (Lewis and others, 1999). However, cryoconite holes are important for creating melt.

The near-surface melt observed in the dry valleys is similar to that found by Liston and others (1999) in Dronning Maud Land, where large areas of subsurface water are found under "blue" (clear) ice. The lower albedo and higher clarity of the blue ice favors subsurface melting due to the "greenhouse" effect (Brandt and Warren, 1993). In comparison, the dry valleys exhibit bubbly-whitish ice, rather than blue ice, and therefore require sediment as the agent of subsurface melt. The resulting melt and refreezing of water increases the ice clarity compared to the surrounding bubbly ice, producing blue-ice-like conditions.

Without sediment on the glaciers to reduce the albedo, cryoconite holes would not develop and meltwater generation would be significantly reduced. From this perspective, cryoconite holes form a transitional hydrologic system between the truly water-covered, supraglacial system common to temperate and polythermal glaciers and the cold and dry ice of the polar interior. In fact, we have observed these hydrologic extremes within our own data record as previously summarized in section 4.2.

\section{SUMMARY AND CONGLUSIONS}

Ice-lidded cryoconite holes are unusual in view of previous cryoconite reports in the scientific literature. Outside of the McMurdo Dry Valleys, the only other reports of ice-lidded cryoconite holes are from northern Greenland (Gaijda, 1958; Nobles, 1960), and those lids melt by mid-summer. Near-surface melt is relatively common in Antarctica. It occurs on the ice sheet in Dronning Maud Land (Liston and others, 1999), on the McMurdo Ice Shelf (Paige, 1968), in the sea ice (Ishikawa and Kobayashi, 1985) and on the lakes of the dry valleys (Chinn, 1993; Adams and others, 1998). The presence of water pools under the ice surface results from a local "greenhouse" effect whereby the rate of turbulent heat loss from the surface exceeds conduction from the radiationally warmed subsurface. The climatic en- 
vironment that favors this process is sunny skies, belowfreezing air temperatures, and winds.

The contribution of subsurface melt to the development and extent of the glacial-hydrologic system is a new hypothesis. The existence of a near-surface hydrologic system challenges our simple definitions of supra- and englacial water systems. About one-half of the holes are well connected hydrologically. Independent cycles of water storage and release occur over short distances in the system. These cycles may result from small differences in solar illumination and shading that cause local freeze-thaw effects, which restrict or enhance water flow. Cryoconite holes are important to generating glacial melt and form a significant component of the hydrologic system of these polar glaciers. Our rough calculations suggest that at least $13 \%$ of the observed runoff from the glaciers can be attributed to melt in cryoconite holes. For the cold environment of the McMurdo Dry Valleys, cryoconite holes and the near-surface water-flow system represent the transitional stage between the watersoaked surface of a temperate or polythermal glacier and an entirely frozen surface of a polar glacier.

About one-half of the cryoconite holes are hydrologically isolated. Based on the conservation of chloride in the hole waters, it is not uncommon to find isolation ages of a few years or more. Ice lids limit the exchange of water and air between the hole waters and the surrounding environment. If biologic material is present, photosynthesis changes the water chemistry dramatically, resulting in waters more typical of African soda lakes than of glacial melt (Tranter and others, 2004). Cryoconite holes may play an important role in the biogeochemical cycling of the dry valleys. Once they become reconnected to the hydrologic system, they inoculate streams with biologic material (Wharton and others, 1985). Also, cryoconite holes may be models for similar refugia on icy planets (Vincent and HowardWilliams, 2000; Nisbet and Sleep, 2001) or on Earth during its hypothesized global glaciation ("snowball earth") 600$800 \times 10^{6}$ years ago (Hoffman and others, 1998).

\section{AGKNOWLEDGEMENTS}

The fieldwork was supported by the U.S. National Science Foundation Office of Polar Programs grants OPP 9211773, 9813061, 9810219 and 0096250. The initial draft of the manuscript was written while A. G. Fountain was on a Leverhulme Fellowship to the Institute for Advanced Studies and to the School of Geography at the University of Bristol, U.K. The support provided is gratefully acknowledged. We appreciate the great help and discussions from our colleagues, W. B. Lyons, R. Johnston, P. Langevin, V. Butler, D. Porazinska and S. Tegt. Field logistics were superbly provided by Antarctic Support Associates, Raytheon Polar Services and PHI Helicopters.

\section{REFERENCES}

Adams, E. E., J. C. Priscu, C. H. Fritsen, S. R. Smith and S. L. Brackman. 1998. Permanent ice covers of the McMurdo Dry Valley lakes, Antarctica: bubble formation and metamorphism. In Priscu, J. C., ed. Ecosystem dynamicsinapolardesert: the McMurdo DryValleys, Antarctica. Washington, DC, American Geophysical Union, 281-295. (Antarctic Research Series 72.)

Adhikary, S., M. Nakawo, K. Seko and B. Shakya. 2000. Dust influence on the melting process of glacier ice: experimental results from Lirung Glacier, Nepal Himalayas. International Association of Hydrological Sciences Publication 264, 43-52.
Agassiz, L. 1847. Système glaciaire ou recherches sur les glaciers, leur mécanisme, leur ancienne extension et le rôle qu'ils ont joué dans l'histoire de la terre. Première partie. Nouvelles études et expériences sur les glaciers actuels: leur structure leur progression, et leur action physique sur le sol. Paris, Victor Masson.

Brandt, R. E. and S. G. Warren. 1993. Solar-heating rates and temperature profiles in Antarctic snow and ice. 7. Glaciol., 39(131), 99-110.

Bromley, A. M. 1985. Weather observations Wright Valley, Antarctica. Wellington, New Zealand. Meteorological Service.

Chinn, T. J. H. 1981. Hydrology and climate of the Ross Sea area. F. R. Soc. N.Z. 11 (4), 373-386.

Chinn, T. J. H. 1985. Structure and equilibrium of the Dry Valleys glaciers. New Zealand Antarctic Record, 6, Special Supplement, 73-88.

Chinn, T. J. 1993. Physical hydrology of the dry valley lakes. In Green, W. J. and E.I. Friedmann, eds. Physical and biogeochemical processes in Antarctic lakes. Washington, DC, American Geophysical Union, 1-51. (Antarctic Research Series 59.)

De Smet, W. H. and E. A. van Rompu. 1994. Rotifera and Tardigrada from some cryoconite holes on a Spitsbergen (Svalbard) glacier. Belg. F. Zool., 124(1), 27-37.

Doran, P.T. and 6 others. 2002. Valley floor climate observations from the McMurdo Dry Valleys, Antarctica, 1986-2000. 7. Geophys. Res., 107(D24), 1-12.

Driedger, C. L. 1981. The 1980 eruptions of Mount St. Helens, Washington. Effect of ash thickness on snow ablation. U.S. Geol. Surv. Prof. Pap. 1250, 757-760.

Drygalski, E. von. 1897. Die Kryoconitlöcher. In Gronland-Expedition der Gesellschaft für Erdkunde zu Berlin 1891-1893. Vol. 1. Berlin, W. H. Kuhl, 93-103.

Fountain, A. G., G. L. Dana, K. J. Lewis, B. H. Vaughn and D. M. McKnight. 1998. Glaciers of the McMurdo Dry Valleys, southern Victoria Land, Antarctica. In Priscu, J.C., ed. Ecosystem dynamics in a polar desert: the McMurdo Dry Valleys, Antarctica. Washington, DC, American Geophysical Union, 65-75. (Antarctic Research Series 72.)

Fountain, A. G. and 12 others. 1999a. Physical controls on the Taylor Valley ecosystem, Antarctica. BioScience, 49(12), 961-971.

Fountain, A. G., K. J. Lewis and P. T. Doran. 1999b. Spatial climatic variation and its control on glacier equilibrium line altitude in Taylor Valley, Antarctica. Global Planet. Change, 22(1-4), 1-10.

Fritsen, C. H. and J. C. Priscu. 1998. Cyanobacterial assemblages in permanent ice covers on Antarctic lakes: distribution, growth rate and temperature response of photosynthesis. F. Phycol., 34(4), 587-597.

Gaijda, R.T. 1958. Cryoconite phenomena on the Greenland ice cap in the Thule Area. Can. Geogr., 3(12), 35-44.

Gerdel, R.W. and F. Drouet. 1960. The cryoconite of the Thule area, Greenland. Transactions of the American Microscopy Society, 79, 256-272.

Gribbon, P.W. F. 1979. Gryoconite holes on Sermikavsak, West Greenland. 7. Glaciol., 22(86), 177-181.

Grongaard, A., P. J. A. Pugh and S. J. McInnes. 1999. Tardigrades and other cryoconite biota on the Greenland ice sheet. Zoologischer Anzeiger, 238, $211-214$.

Hobbs, W. H. 1911. Characteristics of existing glaciers. New York, Macmillan Co.

Hoffman, P. F., A. J. Kaufman, G.P. Halverson and D. P. Schrag. 1998. A Neoproterozoic snowball Earth. Science, 281 (5381), 1342-1346.

Ishikawa, N. and S. Kobayashi. 1985. On the internal melting phenomenon (puddle formation) in fast sea ice, East Antarctica. Ann. Glaciol., 6, 138141.

Kikuchi, Y. 1994. Glaciella, a new genus of freshwater Canthyocamyidae (Copepoda Harpacticoida) from a glacier in Nepal, Himalayas. Hydrobiologia, 292/293(1), 59-66.

Kohshima, S. 1984. A novel cold-tolerant insect found in a Himalayan glacier. Nature, 310(5974), 225-227.

Leslie, A. 1879. The Arctic voyages of A. E. Nordenskjöld. London, MacMillan and Co.

Lewis, K. J. 2001. Solar-forced roughening of Antarctic glaciers and the Martian ice caps: how surficial debris and roughness affect glacial melting in Taylor Valley, and how this can be applied to the Martian ice caps. (Ph.D., University of Colorado.)

Lewis, K. J., A. G. Fountain and G. L. Dana. 1998. Surface energy balance and meltwater production for a Dry Valley glacier, Taylor Valley, Antarctica. Ann. Glaciol., 27, 603-609.

Lewis, K. J., A. G. Fountain and G. L. Dana. 1999. How important is terminus cliff melt?: a study of the Canada Glacier terminus, Taylor Valley, Antarctica. Global Planet. Change, 22(1-4), 105-115.

Liston, G. E., J.-G. Winther, O. Bruland, H. Elvehøy and K. Sand. 1999. Below-surface ice melt on the coastal Antarctic ice sheet. 7. Glaciol., 45(150), 273-285.

Lyons, W. B., K. A. Welch, A. G. Fountain, G. L. Dana, B. H. Vaughn and D. M. McKnight. 2003. Surface glaciochemistry of Taylor Valley, southern Victoria Land, Antarctica and its relationship to stream chemistry. Hydrol. Processes, 17, 115-130.

Margesin, R., G. Zacke and E. Schinner. 2002. Characterization of hetero- 
trophic microorganisms in alpine glacier cryoconite. Arct. Antarct. Alp. Res., 34(1), 88-93.

McIntyre, N. F. 1984. Cryoconite hole thermodynamics. Can. 7. Earth Sci. $21(2), 152-156$

McKnight, D. M., D. K. Niyogi, A. S. Alger, A. Bomblies, P. A. Conovitz and C. M. Tate. 1999. Dry valley streams in Antarctica: ecosystems waiting for water. BioScience, 49(12), 985-995.

Mueller, D. R., W. F. Vincent, W. H. Pollard and C. H. Fritsen. 2001. Glacial cryoconite ecosystems: a bipolar comparison of algal communities and habitats. Nova Hedwigia, 123, 173-197.

Nansen, F. 1906. Protozoa on the ice-floes of the North Polar Sea. In Nansen, F., ed. The Norwegian North Polar Expedition 1893-1896. London, Longmans, Green and Co.; Christiania, Jacob Dybwad, 1-22. (Scientific Results, 5(16))

Nisbet, E. G. and N. H. Sleep. 2001. The habitat and nature of early life. Nature, 409(6823), 1083-1091.

Nobles, L. H. 1960. Glaciological investigations, Nunatarssuaq ice ramp, northwestern Greenland. SIPRE Tech. Rep. 66

Paige, R. A. 1968. Sub-surface melt pools in the McMurdo Ice Shelf, Antarctica. F. Glaciol., 7(51), 511-516.

Podgorny, I. A. and T. C. Grenfell. 1996. Absorption of solar energy in a cryoconite hole. Geophys. Res. Lett., 23(18), 2465-2468.

Porazinska, D. L., A. G. Fountain, T. H. Nylen, M. Tranter and R. A. Virginia 2004. The biodiversity and biochemistry of cryoconite holes from McMurdo Dry Valley Glaciers, Antarctica. Arct. Antarct. Alp. Res., 36(1), 84-91.

Röthlisberger, H. 1972. Water pressure in intra- and subglacial channels. $\mathcal{F}$. Glaciol., 11 (62), 177-203.

Säwström, C., P. Mumford, W. Marshall, A. Hodson and J. Laybourn-Parry. 2002. The microbial communities and primary productivity of cryconite holes in an Arctic glacier (Svalbard $79^{\circ}$ N). Polar Biol., 25(8), 591-596.

Sharp, R.P. 1949. Studies of superglacial debris on valley glaciers. Am. F. Sci. 247(5), 289-315.
Steinböck, O. 1936. Über Kryokonitlöcher und ihre biologische Bedeutung [Cryoconite pits and their biological significance]. Z. Gletscherkd., 24, 1-21. [In German.]

Takeuchi, N., S. Kohshima, Y. Yoshimura, K. Seko and K. Fujita. 2000. Characteristics of cryoconite holes on a Himalayan glacier, Yala Glacier central Nepal. Bull. Glaciol. Res., 17, 51-59.

Takeuchi, N., S. Kohshima, T. Shiraiwa and K. Kubota. 2001a. Characteristics of cryoconite (surface dust on glaciers) and surface albedo of a Patagonian glacier, Tyndall Glacier, Southern Patagonia Icefield. Bull. Glaciol. Res., 18, 65-69.

Takeuchi, N., S. Kohshima and K. Seko. 200lb. Structure, formation, and darkening process of albedo-reducing material (cryoconite) on a Himalayan glacier: a granular algal mat growing on the glacier. Arct. Antarct. Alp. Res., 33(2), 115-122.

Taylor, G. 1916. With Scott: the silver lining. London, Smith, Elder and Co.

Tranter, M., A. Fountain, C. Fritsen, B. Lyons, P. Statham and I. Welch. 2004. Extreme hydrological conditions in natural microcosms entombed within Antarctic ice. Hydrol. Processes, 18, 379-387.

Vincent, W. F. and C. Howard-Williams. 2000. Letters: Life on snowball Earth. Science, 287(5462), 2421.

Wharton, R.A., Jr, C.P. McKay, G.M. Simmons, Jr and B.C. Parker. 1985. Cryoconite holes on glaciers. BioScience, 35(8), 499-503.

Wharton, R.A., Jr and W.G. Vinyard. 1983. Distribution of snow and ice algae in western North America. Madroño, 30, 201-209.

Wharton, R.A., Jr, W.C. Vinyard, B.C. Parker, G.M. Simmons, Jr and K.G. Seaburg. 1981. Algae in cryoconite holes on Canada Glacier in southern Victoria Land, Antarctica. Phycologia, 20(2), 208-211.

Wright, G.S. and R.E. Priestley. 1922. British (Terra Nova) Antarctic Expedition 1910-13. Glaciology. London, Harrison and Sons.

Zellweger, G.W. 1994. Testing and comparison of 4 ionic tracers to measure stream-flow loss by multiple tracer injection. Hydrol. Processes, 8(2), 155-165. 